\title{
Cristóvão Tezza
}

\section{Como você pensa a relação entre o tempo literá-} rio e o tempo histórico?

Não penso. O tempo histórico é uma pressuposição do meu presente, esse, sim, matéria prima de tudo que escrevo.

Quais procedimentos sua obra adota diante de um mundo em que predominam a ação econômica e a espetacularização da arte?

Objetivamente, nenhum. Minha fiç̧ão não é uma resposta objetiva ao mundo; é uma resposta subjetiva, que, ao mesmo tempo, é parte integrante do mundo em que se move. Eu não estou "aqui" e o mundo "lá". Num certo sentido, o mundo sou eu.

\section{Qual reflexão sua obra produz sobre a tradição} literária brasileira?

Mais uma vez, nenhuma reflexão objetiva, porque não é esse o meu modo ficcional de apropriação da linguagem. Só posteriormente, já distante da ação da minha escrita, sou capaz de reconhecer nela traços da minha história literária - que é, aliás, um caos de referências avulsas e fragmentárias, e jamais uma história racional ou teleológica, vinda de algum lugar estabelecido e se dirigindo para outro lugar terraplanado. Sou um escritor cego.

\section{Como você pensa a forma literária?}

Em várias camadas, desde a parte mais superficial (a composição narrativa, a apropriação prévia de um "gênero" - epistolar, confessional, convencional etc.) até o mistério da frase, as mil escolhas sintáticas, a pepita semântica aqui e ali, tudo vai se fazendo por peso $e$ medida, mas não por consciência - como se fosse eu o escrito, e não o texto.

Cristovão Tezza (1952) é autor dos romances Trapo (Brasiliense, 1988), Aventuras provisórias (Mercado Aberto, 1989), Juliano Pavollini (Record, 1989), Uma noite em Curitiba (Rocco, 1995), Breve espaço entre cor e sombra (Rocco, 1998), O fotógrafo (Rocco, 2004) e O filho eterno (Record, 2007). O ensaio Entre prosa e a poesia: Bakhtin e o formalismo russo (Rocco, 2003), resultou de sua tese de doutorado. 